\title{
Juridical and Philosophical Aspects of Joint Land (Gandhok/Gamblok) Ownership System: Adat Land Law Perspective
}

\author{
Sulastriyono \\ Faculty of Law, Gadjah Mada University, Yogyakarta, Indonesia. \\ E-mail: sulastriyono@yahoo.com/sulastriyono@mail.ugm.ac.id
}

\begin{tabular}{l} 
ARTICLE INFO \\
\hline Keywords:. \\
Adat Land Law, Joint \\
Land, Land Ownership. \\
How to cite: \\
Sulastriyono. Juridical and \\
Philosophical Aspects of \\
Joint Land \\
(Gandhok/Gamblok) \\
Ownership System \\
According to Adat Land \\
Law. MEDIA HUKUM, \\
+62 274 387656 (Ext. 220) \\
Article History \\
Received: 04/01/2019 \\
Reviewed: 29/05/2019 \\
Revised: \\
Accepted: 25/06/2019
\end{tabular}

\begin{abstract}
Joint land ownership has been in existence for long time in Indonesia, especially in Java. Such a unique ownership system has inherent problem, namely potential conflict among the factual owners. This article aims to analyze the philosophical background of joint land ownership and its legal problems. This normative legal research was conducted through library-based study. It is found that there are three contributing factors that created the joint land ownership system. These include historical factors, philosophical factors, and the change of land economic value. In the past, joint land ownership system was introduced by the head village (bekel) to alleviate the burden of the tax payment. The philosophy of joint land ownership system refers to the philosophy of farmer life that can be identified from several values such as mutual trust and honesty in the spirit of kinship/togetherness.
\end{abstract}

DOI: 10.18196/jmh.20190120

Copyright (C) 2019 MEDIA HUKUM. All rights reserved.

\section{Introduction}

Humans have close relationship with land. In Javanese culture there is a proverb clarifying the importance of land that is: sedumuk bathuk senyari bumi den lakoni taker pati, sanadyan pecahing dhadha wutahing ludira. ${ }^{1}$ For Javanese people, land is a valuable object that authorizes the owner to protect it with physical power from any illegal acquisition. Land ownerships is a crucial issue within social life. The governance of land ownership has created legal relationship between humans and land. The land owner enjoys the so-called land rights.

Maria S.W. Sumardjono defines land rights as a control right over the earth which

1 Sastroatmodjo, S. (2007). Sedumuk Bathuk Senyari Bumi, Regulasi Tanah dan Demo Rakyat (Petani) dalam Menyoal Hak Atas Tanah. Kompas Mahasiswa. Edisi 79. p. 28. 
authorizes the holder to use the land, water and air above it, only what is needed to fulfill the interests directly related to use the land is based on restrictions regulated by the Basic Agrarian Law (BAL). Individual rights to land have existed since individuals controlled the land.2

The land ownership system constantly evolves in accordance with the development and needs of the community. One of crucial issues relating to land in Indonesia is joint land ownership. The ownership system of joint land (gandhok/gamblok) that has been in existence for long time within the legal history brings about negative impact. Joint land in this sense refers to the joint ownership of a land. In this system, that land is actually owned by several people, however for the legal purpose, it is put (digandhokkan/digamblokkan) under the name of an owner. ${ }^{3}$

As reported in the media, the implementation of this system creates legal problems in the form of conflicts/disputes in the process of transferring land due to inheritance, buying and selling. ${ }^{4}$ It is interesting to analyze the philosophical background of joint land ownership and its legal problems.

\section{Method}

This study of the system of land ownership in gandhok/gamblok was carried out with the specifications of customary land law. The material of this study includes secondary data, namely data obtained from library research that examines historical background and potential conflicts/disputes. The technique of collecting data in this library research is by studying documents that are critically reading library materials for customary land law books, legislation, articles from newspapers, the internet, research journals. The collected data is processed data by sorting the data according to the subject matter under study. In the next stage is qualitative data analysis by integrating data, that is relevant to the problem with the theory, principles, and doctrines of customary law. Data has been analyzed qualitatively. Afterward, it is rearranged in exposure to research report articles that are ready to be sent to research journals.

\section{Analysis and Results}

\subsection{Background/History of Land Ownership in Philosophical and Juridical} Jurisprudence

\subsubsection{Land Ownership System of Kingdom Era on Java}

The kingdoms that existed in Java in the past were the concrete manifestations of a country because they had fulfilled the basic elements of the state, namely: having land, population, government, and the legal system. Land is an important element of the country because the land is a place used for various activities in people's lives. Besides land, another important element of the state is the people and the legal system that governs the lives of the people.

Land ownership system is a form of a legal system that regulates various aspects of the

\footnotetext{
2 Santoso, U. (2012). Hukum Agraria dan Hak-hak atas Tanah. Jakarta: Kencana. p. 78.

${ }^{3}$ Isnur, E.Y. (2009). Tata Cara Mengurus Surat-surat Rumah dan Tanah. Yogyakarta: Pustaka Yustisia. p. 44.

4 Wahono, T. (2010). Sistem Gandok Picu Sengketa Lahan, http://regional kompas.com/read/2010/08/05/18473127/accessed on March 30, 2017.
} 
land. Historically, the system of land ownership in Java during the kingdom era was the king as the absolute owner of the land, in whose management the king had subordinates to regulate these lands. ${ }^{5}$ The system of land ownership in the royal period is divided into two lands, namely: land owned by the king directly and land that is not directly owned by the king. Land directly owned by the king is land in the royal fortress and certain places that are directly used for king activities such as the palace, the square, the market, the garden, the tomb of the king and the place of rituals/royal ceremonies. Land that is indirectly owned by the king is land that is outside the royal fortress and not places that are used for king activities.

Geographically, the land in the kingdom territory is divided into 3 types: namely the land that is in the capital city of the kingdom called kuthanegara, land outside the kuthanegara of the kingdom called negaragung, and land outside the nagaragung called mancanegara. In the territory of negaragung distinguish earth of pamajegan, pangrembe, and gladag. ${ }^{6}$ Earth of pamajegan is the land of the king that produces tax on crops. The Pangrembe area is land planted with rice or other plants for the palace. Earth gladag is a land whose inhabitants get transportation assignments.

The land which is located in the negaragung is not owned directly by the king, but the king is helped by families who are called patuh. The patuh do not live in the negaragung but in kuthanegara. The Patuh in carrying out their duties is assisted by bekel who live in the negaragung. Patuh's duty is to supervise and coordinate with the bekel in terms of withdrawal/collection of agricultural products, land processing, community service, night patrol of its citizens.

Patuh and bekel do not get a salary from the kingdom, but, patuh gets a portion of the proceeds from collecting the produce from the farmers. The bekel was given power over the land by the king to be processed by involving local farmers. Some of the crops that farmers cultivated for the royal treasury. ${ }^{7}$ The offering of produce from the farmer to the king was not directly but through the intercession of the bekel and passed on to the patuh, which then the patuh surrendered to the king through the royal treasury. Suhartono added that the king's mother and the king's wife each received lungguh land 10,000 works, Adipati anom with an area of 8,000 works, Wedana Lebet had land of 5,000 works/cacah (chopped). ${ }^{8}$ The term work/cacah refers to farmers cultivating rice fields. At that time, 1 (one) jung of approximately $28,386 \mathrm{~m} 2$ were worked by four works/cacah (sharecroppers).

In its development, Bekel became the village head as the sole ruler in a village who was also responsible for the field of order and village security. For his services to the king and patuh, the farmer has the right to get $1 / 5$ (one fifth) of the yield of the rice fields, while $2 / 5$ for the king and 2/5 for bekel and patuh..$^{9}$ In addition, there are patuh and bekel structures among farmers; there also appears to be a classification of the people

\footnotetext{
${ }^{5}$ Ham, O.H. "Perubahan Sosial di Madiun Selama Abad XIX: Pajak dan Pengaruhnya Terhadap Penguasaan Tanah". on Sediono M.P. Tjondronegoro dan Gunawan Wiradi (ed.). (1984). Dua Abad Penguasaan Tanah Pola penguasaan Tanah Pertanian Di Jawa dari masa ke Masa. Jakarta: Penerbit Yayasan Obor Indonesia dan Gramedia Indonesia. p.5.

6 Wasino. (2005). Tanah Desa, dan Penguasa: Sejarah Pemilikan dan Penguasaan Tanah di Pedesaan Jawa. Semarang: UnNes Press. p. 29.

7 Pusponegoro, M.D. at al. (1984).Sejarah Nasional Indonesia Jilid IV. Jakarta: Balai Pustaka.p. 20.

8 Suhartono. (1991). Apanage dan Bekel, Perubahan Sosial Dipedesaan Surakarta (1830-1920). Yogyakarta: Tirta Wacana Yogya. p. 30.

${ }^{9}$ Ibid, p. 31.
} 
related to the land ownership system, namely farmers in the kuli kenceng group, and kuli kendho group. ${ }^{10}$ First group farmers (kuli kenceng) as village elites. The kuli kenceng group, which is a farmer who has full obligations and rights as a villager, namely paying taxes on crops to the kingdom, obligatory work for the kingdom, community service/ village mutual cooperation, village night patrol. The rights of village elites are the right to be elected as the village head (bekel). The second group of farmers is kuli kendho, namely ordinary farmers consisting of karang kopek farmers, indung gandhok/ gamblok farmers, and indung tlosor farmers. Karang kopek farmers are farmers who only have their own land and house but do not have rice fields (cultivated).

Philosophically, the purposes of the division of people in many groups to determine of an elite farmer who entitled to become a village head. The ordinary group of farmers were not entitled to become a village head and not obliged to pay tax on produce to the king and is not required to work for the kingdom. The criteria used by the kingdom to pay taxes on crops is the ownership of land so that farmers who do not rice field do not pay taxes on crops. The criteria for farmers who are obliged to work for the kingdom are men (family heads) of farmers so that the obligation to work for the kingdom from the head of the family for farmers can be represented by sons. This situation is a legal loophole that can provide the opportunity for farmers to carry out legal smuggling and philosophically to avoid the obligation to pay taxes on crops and mandatory work obligations for the kingdom.

\subsubsection{Land Ownership System during the Occupation/ Colonial Period}

The system of land ownership during the colonial period took the concept of a system of land ownership in the kingdom. Since Dutch colonized Indonesia by conquering the kingdoms in Indonesia, the land ownership by the king moved to the colonial government. Historically, the beginning of the change in the system of land ownership during the colonial period was when the Verenigde Oost Indische Compagnie (VOC) began to develop in Java and began to make agreements with the kingdoms on Java. The territory of Mataram slowly experienced a reduction in the territory, when the Giyanti Agreement was made in 1755, the coastal area already belonged to the VOC. The Surakarta and Yogyakarta regions are only kuthanegara, negaragung, and mancanegara.11 It means that land outside the manacanegara is owned by the VOC.

After the VOC broke up in 1789, the government in Indonesia was continued by the colonial government. Governor General Daendels by implementing forced planting politics has changed the system of land ownership by farmers by providing opportunities to all groups of farmers, both of kuli kenceng farmers and kuli kendho farmers (indung gandhok/gamblok, indung tlosor, karang kopek) to obtain cultivated land. The land cultivated by the farmers is land that can also be inherited. The land originally came from the land of the sikêp, which was taken over by the village government and distributed to farmers to open new areas in the local village. According to Hiroyoshi Kano, the system of forced cultivation has changed the system of agricultural land ownership among farmers, namely belonging to hereditary

${ }^{10}$ Ham, O.H. on Wiradi, G. (ed). Op. Cit. p. 7.

11 Wasino. Op. Cit. p. 19. 
individuals (erftelijk individueel bezit), communal property (gemeen bezit), and crooked land for village staff (pamong desa; ambtsvelden). ${ }^{12}$

Governor General van Heutz ordered that a system of land ownership be implemented immediately by abolishing the system of land ownership in an apanage, so that in the Surakarta area the system of land ownership by the king and carried out by compliant with temporary borrowing rights were abolished and land rights it is given to farmers with own (andarbe) rights individually. ${ }^{13}$

\subsubsection{Land Ownership System after Independent Period}

Article 33 paragraph (3) of the 1945 Constitution explains that the earth, water, and natural resources contained therein are controlled by the state and are used for the greatest possible welfare of the people. Since then, the land ownership system in Indonesia has changed. Originally in the kingdom and occupation, the concept of the king/state having land was shifted into the concept of the state controlling the land.

In 1960 with the enactment of Law Number 5 of 1960 concerning BAL, the system of land ownership was applied to the principle that land was controlled by the state but also recognized the existence of individual property rights over land. Article 19 of the BAL also stipulates that the government implements land registration in Indonesia. Land problems arise when is still implemented the combine (gandhok/gamblok) the land ownership system. When farmers/landowners will transfer land rights by inheriting land to heirs or selling. Legal problems in the form of conflicts/disputes about this system emerged when the former village head lost the election as the new village head, then the former village head destroyed/damaged the land book in the village office. The other legal problem emerged when the village head had changed many times and there was no coordination with the new village head for the continuation of land administration in the village office. The absence of land books in the village office occurred when there were individuals from the former village head who destroyed the land book in the village office (letter C, letter D or letter E). This condition is exacerbated when until now the National Land Agency (BPN) has not succeeded in registering all parcels of land in its working area while the main source of proof of land ownership in the village office is letter C, letter Datau Letter E is not destroyed.

Philoshophy of the implementation of combine (gandhok/gamblok) in the adat land law, when in the kingdom period, colonial and after Indonesian Independent era is a mutual trust and honesty with a family spirit in human life due to the good faith of the bekel/village head to the farmers. It is said to provide relief and convenience because when citizens who are burdened with tax payments and burdens are obliged to work a lot, it means burdening the people/farmers. This also means that the bekel/village head's duty is more difficult in coordinating with people. On the other hand, when the people whose names are used as the basis for tax collection and mandatory employment are not many, then the burden of the people/farmers is simpler and the bekel/village head is easier to carry out mandatory coordination of work for farmers. The value of human honesty appears in behaving/human actions in various aspects of

\footnotetext{
12 Kano, H. "Sistem Pemilikan Tanah dan Masyarakat Desa di Jawa Pada Abad XIX". on Sediono M.P. Tjondronegoro dan Gunawan Wiradi (ed). (1984). Dua Abad Penguasaan Tanah: Pola Penguasaan Tanah Pertanian di Jawa dari Masa ke Masa. Jakarta:Yayasan Obor Indonesia dan Gramedia, Indonesia. p. 42. 13 Suhartono. Op. Cit. p. 101.
} 
social life. In the context of the lives of farmers/people who apply the system of land ownership in the implementation of combine (gandhok/ gamblok,) the philosophy of life of mutual trust and honesty in acting is a mandate that is not light. This is because in that system, is the name officially written in the land book in the village office. Therefore the owner whose name is written in the land book in the village office is sued honestly and delivered to the family (children and wife) and landowners who place their names in land ownership.

\subsection{Potential Conflict/Dispute of The Implementation of Combine (Gandhok/Gamblok) Land Ownership System in The Adat Land Law}

The aspect of legal history, the system of land ownership in the implementation of combine (gandhok/gamblok) is related to the citizenship status of a person in a adat law community. During the kingdom and occupation era was the population/villager as members of the adat law community unit. At that time the villagers were distinguished from the core villagers called kuli kenceng (Baku, gogol, sikep, pribumi); kuli kendo (karang kopek, indung gamblok, kuli gundhul, magersari; mondhok emplok /indung tlosor) because they do not have cultivated land and grounds. ${ }^{14}$ The background of the system of land ownership in the implementation of combine (gandhok/gamblok) is the effort of the people/farmers to avoid the burden of paying taxes and work obligations for the kingdom and for the invaders. In the kingdom and the occupation period, the tax burden of the produce, it was felt heavy by peoples because they had to submit $2 / 5$ parts to the kingdom and 2/5 parts to patuh and bekel. The farmers only received $1 / 5$ part of the crop. Besides that, farmers are also required to work (herendienst) as a form of devotion to the kingdom and invaders. The people in facing this heavy burden then carried out legal smuggling. The legal smuggling is in the form of an agreement with his family/siblings to collect/pledge his land to his brother as the land owner recorded in the land book/letter C, D, or letter E with the smuggling of the law the tax burden and the required heavy labor become more light because the burden can be shared with a number of people whose names in land ownership.

In daily life, the words conflict and dispute are two words that are often considered the same in terms of the two words having different meanings. Conflict is a translation of conflict and dispute is a translation of dispute; a conflict will not develop into a dispute if the party who feels disadvantaged only harbored dissatisfaction or concern. A conflict develops into a dispute if the party who feels aggrieved has expressed dissatisfaction.

\subsubsection{Definition of Land Conflict/ Disputes}

Land conflicts or disputes are disputes that occur between two or more parties who feel or are harmed by these parties for the use and control of their land rights, which are resolved through deliberation or court. According to Rusmadi Murad, understanding land disputes or disputes over land rights, namely the emergence of legal disputes, which originate from complaints of a party (person or entity) that contains objections and claims for land rights, both to the status of the land, priority, and ownership in the hope of obtaining administrative settlement in accordance with

14 Kroef, J.V.D. Penguasaan Tanah dan Struktur Sosial di Pedesaan Jawa. on Sediono MP. Tjondronegoro dan Gunawan Wiradi (ed) (1984). Dua Abah Penguasaan Tanah Pola Penguasaan Tanah Pertanian di Jawa dari Masa ke Masa. Jakarta: Yayasan Obor Indonesia dan Gramedia Indonesia. p. 161. 
regulatory provisions apply. ${ }^{15}$ According to Edi Prajoto, land disputes are conflicts between two or more people who have the same interest in the status of land object rights between one or several land objects that can result in certain legal consequences for the parties. ${ }^{16}$ According to Irawan Surodjo, land disputes are conflicts between two or more parties that have different interests towards one or several objects of rights or land, which can result in legal consequences for both. ${ }^{17}$ In this article what is meant by conflicts/disputes over ownership systems in the implementation of the combine (gandhok/gamblok) are juridical and philosophical problems that arise because of differences of opinion from two or more parties in the implementation of combine (gandhok/gamblok) land ownership system.

\subsubsection{Cause Conflict/ Disputes}

Conflict/dispute usually starts from a situation where there is a party who feels aggrieved by another party, which begins with subjective and closed feelings of dissatisfaction. Dissatisfaction comes to the surface if there are parties who feel dissatisfied submit objections. An escalation conflict leads to a dispute through the dispute process because there is no meeting point between the parties in conflict. Potentially, two parties that have different opinions or opinions have the potential to move to a dispute situation.

According to Ida Nurlinda, conflicts/disputes over land rights and rights boundaries are also triggered by a large number of land that has not yet been certified. ${ }^{18}$ Philosophy, the system of land ownership in the implementation of the combine (gandhok/gamblok) is used by the community to facilitate local communities to simplify data in land ownership. However, in reality, it has become a time bomb for farmers/people themselves for the emergence of conflicts/disputes. The complexity of land law (conflict/dispute) issues during the Dutch colonial period cannot be compared with the complexity of current legal issues (conflicts/disputes). During Dutch colonialism, a bekel/village head had extensive authority. At that time the authority of the village head was regulated autonomously by the village. This is one of the driving forces for the system of land ownership in combine (gandhok/gamblok) because during the Dutch colonial period the bekel/village head had more free authority in determining the name system the implementation of the combine (gandhok/gamblok).

The system of land ownership in the implementation of the combine (gandhok/gamblok) adheres closely to a proof of ownership of the past land before it is known as a certificate of land but only a land letter in the form of Letter C, D, E or Girik (proof of payment of tax). The land letter is a product of Dutch colonial heritage. Letter C contains the area and class of land and the parcel number, regarding the name of the owner, and regarding the amount of tax. Letter $C$ is a list of land, name of the owner with a serial number, and amount of tax. The debate about the legality of Letter $C$ is still a polemic in the community. This also propagates the problem of this system where if Letter $C$ cannot be said to be a strong evidence, the legality of this system is increasingly blurred. Letter $\mathrm{C}$, is actually a strong evidence, because if a piece of land

\footnotetext{
${ }^{15}$ Murad, R. (1991). Peyelesaian Sengketa Hukum atas Tanah, Bandung: Penerbit Alumni. p. 22.

16 Prajoto. R. (2006). Antimoni Norma Hukum Pembatalan Pemberian Hak Atas Tanah oleh Peradilan Tata Usaha

Negara dan Badan Pertanahan Nasional. Bandung: CV. Utomo. p. 21.

17 Surodjo, I. (2003). Kepastian Hukum Atas Tanah di Indonesia. Surabaya: Arkola. p. 12.

18 Nurlinda, I. (2009). Prinsip-prinsip Pembaruan Agraria Perspektif Hukum. Jakarta: Rajawali Pers. p. 169.
} 
has not yet been certified, then there is probably only a tax statement (girik, Pethuk pajek Letter C).

The problem of the land ownership system in the implementation of combine (gandhok/gamblok) in the present time is increasingly complex because it is veiled from the law, there is no nomenclature regarding it, and if the land owner did not tell his child and wife so that the child and wife understood all the land was the land of the heir. This system is a hidden legal smuggling because its system is to avoid high taxes from the kingdom and invaders.

The people/farmers do various ways to overcome conflicts/disputes regarding land ownership in the implementation of combine (gandhok/gamblok). In adat law, the landowner who requests his name to his/ her family then legally it can be said that the original owner implemented a land ownership agreement with his brothers.

\subsubsection{Factors of Causing Conflict/Disputes}

\section{a. Historical Juridically Factors}

Land ownership system in the implementation of the combine (gandhok/gamblok) is closely related to proof of land ownership in the past, namely land letter (Letter C, D, E). Land letter (Letter C, D, and E) is a product of Dutch colonial heritage. Historically there was an agreement to borrow names. A family with more than one child made an agreement that the name of the landowner written in the village land book was one of them who was usually the oldest son in the family. The younger siblings in the family are requesters (penggandhok/penggamblok). The meaning of the agreement is known by bekel/village head that the land is not only the private property of the person whose name is officially listed in the land book but also belongs to his younger siblings but their name is not listed in the land book.

At this time, there was still a case of land ownership system in the implementation of the combine (gandhok/gamblok) to his brother name, because there was no transfer of this land rights. There are many requesters (penggandhok/penggamblok) who still live together in one area with official landowners that listed in the land book, but many of them live elsewhere in the city. This system grows and develops in the Village/community of Yogyakarta and Surakarta, while the community outside of Yogyakarta and Surakarta does not implement this system.

Based on historical juridically factors, the system of land ownership in the implementation of the combine (gandhok/gamblok) is also caused by the opportunity gaven by the bekel/village head to the farmers. The landowners combine their land rights to their siblings or others (kuli kenceng) so that the burden of farmers in paying taxes and compulsory work is not too heavy. This opportunity is referred to as legal smuggling, which is an act carried out to deviate from the existing rules so that the burden/obligation is not too heavy. The other legal problem of conflict/dispute over land ownership system in the implementation of the combine (gandhok/gamblok) during the early independence period until now appears/potential arises due to the provisions that the tenure of the village head is limited to 8 years and a maximum of two periods. The legal problem arose after the village head experienced a change of village head from one village head to the new village head. It is possible that 
the new village head did not understand this system. The administration system of land ownership in the village book in the form of Letter C, letter D or letter $\mathrm{E}$ in the village office was not carried out properly by the village head and other village officials.

\section{b. Changing Factor of The Farmer's Philosophy}

In the past, namely when the kingdom and colonialism era, the farmers who implemented a system of land ownership in the implementation of the combine (gandhok/gamblok) with the philosophical life mutual trust and honest by applying harmony in a family atmosphere. The farmers live in conditions of complete deprivation, so simplicity is a life choice that must be lived. Under these conditions, the living farmers help each other to help in the atmosphere of living in harmony with the spirit of kinship/togetherness. Between the requesters (penggandhok) and his brother listed in the land book, there is an agreement, then they trust and are honest in carrying out their mandate. In this context, there is no need for authentic evidence from that agreement. The names of brothers as landowners are not listed in the letter C, D, or E, but they agree to combine (gandhok/gamblok) their land to the landowner whose name is listed on C. If there is a problem should be resolved with the togetherness principle and relies based on deliberation.

In line with the development and the openness of information, the philosophy of life of mutual trust and honesty with the spirit of kinship/togetherness was eroded by the globalization which to prefer implement the hedonic and consumptive lifestyle. The life patterns of many farmers have begun to shift towards a hedonic and consumptive lifestyle so that they have symptoms that are no longer trustworthy and dishonest and put forward the values of individualism. Many of the landowners in the implementation of the combine (gandhok/gamblok) have started to be untrustworthy and dishonest to their children and wives even to themselves. When there are financial needs, the land owner whose name is listed in the land book can sell the land. The selling process does not experience obstacles because the name listed in the book land/land letter is the name of the owner who will sell the land in the event that the land is not private land but also the land belonging to his brothers that is not listed in the land book/letter C. This condition is certainly detrimental to the requesters (penggandhok/penggamblok) and tend to emerging conflicts/disputes between landowners and their siblings as requesters. Conflict/dispute over land ownership system in the implementation of the combine (gandhok/gamblok) arises when there is a person who receives land entrusted with a request (gandhok/gamblok) not honestly informs/tells his child and wife. This caused his child and wife do not know even do not want to know if the land belongs not only to his father/husband but also belongs to the brothers who combine the land. When his father/husband died, the only proof of ownership of land in the land book was his father's/husband name so that his child and wife argued that the land was owned by his father/husband, not his father's/husband's brothers. In this condition, land conflicts/disputes emerged in the implementation of combine (Gandhok/Gamblok) land ownwership system.

\section{c. Factors of Changing Land Economic Value}


The system of land ownership in the implementation of the combine (gandhok/gamblok) has the potential for conflicts/disputes to arise due to changes in the economic value of the land. In the past, when the population was still small, and the land was still widely available, economically, the land was of little value. In its development, when the population grew more and more while the land was relatively fixed, there was a tendency for land prices to rise. With the change in the economic value of the land means owning land is the same as having assets/capital. In a formal legal system of land ownership in the implementation of the combine (gandhok/gamblok), the name of the landowner is only one person, but the fact that the land is owned by more than one person.

The policy of the kingdom, Dutch colonial and Indonesian government which allowed the application of land ownership systems in the implementation of the combine (gandhok/gamblok), was a time bomb to cause conflicts/disputes that arose later on. This is because this system is related to the landowners (penggandhok/penggamblok) whose name have not been listed in the land book in village office to the person whose name is contained in the land book in the village office (Letter C, D, or E). Name of the land owner in the land book based on custom is the oldest son. Inclusion of the name is done carefully to brother/family. The things that must be considered are: someone has a family relationship with the land owners. Indeed, there are still other matters considered by the owner, whose name is formally stated as the land owner. These considerations are personal, so they can only be seen on a case by case basis. All of these criteria are relative because the consideration of each original owner is different, but the above can be used as a basis for entrusting the land. The system of land ownership in implementation combine (gandhok/gamblok) because the habits of the people/farmers in the past resulted in potential conflicts/disputes in the present and future.

\section{Conclusion}

Based on the analysis discussions, it can be concluded that: Firstly, the legal history of the system of land ownership in the implementation of the combine (gandhok/gamblok) in adat land law in Yogyakarta and Surakarta is distinguished in three periods, namely the kingdom period, the colonial period, and the independent period. The philosophical background of land ownership in the implementation of combine (gandhok/gamblok), because: (a) the philosophy of life is mutual trust and honesty in the spirit of kinship/togetherness. (b) the binding philosophy of the bekel/village head to alleviate and provide facilities for the people because of the burden of the tax on produce and the very heavy work required. Secondly, the potential conflict/disputes the land ownership system in the implementation of the combine (gandhok/gamblok) is due to juridical historically factors, philosophical factors, and change of land economic value.

\section{Acknowledgments}

We gratefully acknowledge the financial support, from the Faculty of Law of Universitas Gadjah Mada. 


\section{References}

Books:

Ham, OH. "Perubahan Sosial di Madiun selama Abad XIX: Pajak dan Pengaruhnya Terhadap Penguasaan Tanah", on Sediono M.P. Tjondronegoro dan Gunawan Wiradi (ed.) 1984.Dua Abad Penguasaan Tanah Pola penguasaan Tanah Pertanian Di Jawa dari masa ke Masa. Jakarta: Penerbit Yayasan Obor Indonesia dan Gramedia Indonesia.

Isnur, YE. (2009). Tata cara mengurus Surat-surat Rumah dan Tanah. Yogyakarta:

Kano, H. "Sistem Pemilikan Tanah dan Masyarakat Desa Di Jawa Pada Abad XIX". On Sediono M.P. Tjondronegoro dan Gunawan Wiradi (ed) 1984. Dua Abad Penguasaan Tanah: Pola Penguasaan Tanah Pertanian di Jawa dari Masa ke Masa. Jakarta: Yayasan Obor Indonesia dan Gramedia Indonesia.

Kroef, JVD. . "Penguasaan tanah dan Struktur Sosial di Pedesaan Jawa", On Sediono M.P. Tjondronegoro dan Gunawan Wiradi (ed).1984. Dua Abah Penguasaan Tanah pola penguasaan tanah Pertanian di Jawa dari masa ke masa. Jakarta:Yayasan Obor Indonesia dan Gramedia Indonesia.

Murad, R. (1991). Penyelesaian Sengketa Hukum atas Tanah, Bandung: Penerbit Alumni.

Nurlinda, I. (2009). Prinsip-prinsip Pembaruan Agraria Perspektif Hukum. Jakarta: Rajawali Pers.

Poesponegoro, MD dan Notsusanto,N. (1984).Sejarah Nasional Indonesia Jilid IV. Jakarta: Balai Pustaka.

Prajoto, E. (2006). Antimoni Norma Hukum Pembatalan Pemberian Hak Atas Tanah oleh Peradilan Tata Usaha Negara dan Badan Pertanahan Nasional. Bandung: CV.Utomo, Pustaka Yustisia.

Santoso, U. (2012). Hukum Agraria dan Hak Hak atas Tanah, Jakarta: Kencana.

Soerodjo, I. (2003). Kepastian Hukum Atas Tanah di Indonesia. Surabaya: Arkola.

Suhartono. (1991). Apanage dan Bekel, Perubahan Sosial Dipedesaan Surakarta (18301920).Yogyakarta: Tirta Wacana Yogya.

Sumardjono, MSW. (2008), Tanah Dalam Perspektif Hak Ekonomi, Sosial dan Budaya. Jakarta: Gramedia Pustaka Utama.

Wasino. (2005). Tanah, Desa, dan Penguasa: Sejarah Pemilikan dan Penguasaan Tanah di Pedesaan Jawa. Semarang: Unnes Press.

World Wide Web:

Tri Wahono. 2010. "Sistem Gandok Picu Sengketa Lahan". http// regional kompas.com/read/2010/08/05/18473127/accessed on March 30, 2017.

\section{Newspaper:}

Sastroatmodjo, S.(2007). Sedumuk Bathuk Senyari Bumi, Regulasi Tanah dan Demo Rakyat (Petani) dalam Menyoal Hak Atas Tanah. Kompas Mahasiswa. Edisi 79. 